\title{
ROMEO AND JULIET: A NEW CONTEXT FOR VICTORY?
}

\author{
Nic Panagopoulos \\ National \& Kapodistrian University of Athens
}

\begin{abstract}
The contention of the present comparative study is that the closest Shakespearean work to Conrad's Victory is not The Tempest, as has previously been thought, but Romeo and Juliet. Besides various thematic links between these two texts, also noted by Adam Gillon (1976), I argue that Victory and Romeo and Juliet are connected on the level of genre, plot, and characterization, with whole scenes in Conrad's novel mirroring those in Shakespeare's play. In conclusion I suggest that the striking similarities between the two works can either be explained by a conscious desire on Conrad's part to imitate Shakespeare's art, or by a kind of involuntary emulation, whereby the novelist had so far assimilated the Bard's work as to follow it unconsciously while composing his own novel.
\end{abstract}

Keywords: Conrad and Shakespeare, tragedy/comedy, mirroring, Victory, Romeo and Juliet, comparative study, cryptomnesia

In his famous extended essay "Joseph Conrad and Shakespeare," the late Adam Gillon does a remarkable job of tracing the many textual and thematic parallels between Conrad's major works and virtually the whole Shakespearean canon. He begins by pointing out that Conrad could have read The Two Gentlemen of Verona at the age of eight as his father was translating many of the Bard's works into Polish around 1856. As is often the case, Shakespeare must have been one the first writers that the young and impressionable Conrad was exposed to, and certainly one of the first English writers in that category. Another significant detail noted by Gillon is that Conrad read A. C. Bradley's Shakespearean Tragedy while writing Victory, perhaps with a view to giving his work a tragic, or, more specifically, a Shakespearean note. Conrad also seems to have nursed a "secret," yet oft-expressed, desire to write a play, which resulted in his daring albeit ill-fated stage adaptations of Victory and The Secret Agent. Hence, a picture of a writer with dramaturgical aspirations emerges. Gillon's essay suggests as much, and besides noting that "many of [Conrad's] novels and stories were conceived in dramatic terms" (90), he argues that Conrad and Shakespeare share common preoccupations, such as the idea that life is a dream or an illusion, a destructive darkness that negates human aspirations, and an ordeal that tests the

${ }^{1}$ Letter to Edward Garnett, January 20, 1900 in G. Jean-Aubrey, II, p. 276. 
hero's mettle. Conrad is thus presented by Gillon as essentially a tragic writer who, besides subscribing to the Shakespearean theatrum mundi, does not interpret "man's failure, the futility of his efforts, and finally his death" (59) as a defeat.

When it comes to Victory, Gillon quite rightly asserts that "Conrad's use of Shakespearean archetypes [...] reaches a culminating point" there, which reflects "the overwhelming impact of Shakespeare on Conrad at the time of his writing the novel" (85). Yet, like most critics before him, Gillon assumes that Conrad's novel draws mostly on The Tempest, which it outwardly resembles, with the Prospero-like figure of Heyst, who is trying to protect the Miranda-like Lena from the hostile invaders of their island refuge. ${ }^{2}$ In comparing these two works, Gillon briefly mentions some images common to Victory and Romeo and Juliet, which are, however, viewed by him as relating to the recurring Shakespearean motifs in general rather than the two particular works in question. For example, the critic notices that names and books seem to be significant in both works, but he links the former issues to Coriolanus while the latter one to Hamlet. He likewise observes that the "animal imagery, so often employed in Shakespeare" (92), also appears in the presentation of the characters in Victory, but fails to relate this imagery specifically to Romeo and Juliet, in which the Prince, having interrupted the escalating (is there a pun on Escalus here?) street brawl in the first scene, chastises his unruly subjects with the memorable phrase: "What, ho - you men, you beasts" (I.1.83), thus introducing the theme of uncontrollable instincts, which is central to Shakespeare's tragedy, as well as inaugurating a characteristicplethora of human-animal comparisons. Gillon does, however, claim that "Conrad's ironic treatment of love in Victory draws on the genuinely romantic imagery of Romeo and Juliet" (112), although this may be countered by saying that Conrad's treatment of love in his novel may not be as "ironic," nor the romantic imagery in Shakespeare's play as "genuine" as that.

The link between Victory and The Tempest, which most commentators on the novel's Shakespearean quality have pointed out, seems considerably more problematic than has hitherto been assumed. For one thing, Victory is not centred on a fatherdaughter relationship as is Shakespeare's comedy but on an illicit love affair between an older man and a younger woman, whose age enhances the issue of a paternal impulse on the male side, very much like the one characterizing Prospero. Heyst is indeed old enough to be Lena's father (she is not yet twenty and he is over thirty five), but it is the erotic element in their relationship, masquerading as chivalry, that has the power to dismantle the man's stoical defences, and prompt him to act. Heyst Senior's statement foreshadows the situation when he writes: "Of the stratagems of life the most cruel is the consolation of love-the most subtle, too; for the desire is the bed of dreams" (Victory 184).

Where the comparison between Victory and The Tempest breaks down, however, is with the Shakespearean magician/artist's virtual omnipotence on his island, in stark contrast to Heyst's inability to impose himself, which constitutes the single most important aspect of the ensuing tragedy. In this respect Heyst is much closer to

${ }^{2}$ For previous studies on the subject, see: Baines, Karl, Lodge and Dike. 
Romeo, who, while entertaining suicidal thoughts after being exiled by the Prince, is reprimanded by Friar Lawrence in the following prophetic words: "Wilt thou slay thyself? / And slay thy lady that in thy life lives" (III.3.116-7). Indeed, in both Victory and Romeo and Juliet the patriarchal power structure of The Tempest's central relationship is noticeably subverted, with Lena turned into a protective mother-figure for her would-be Quixotic deliverer, just as Juliet is transformed literally overnight from a typical teenage Renaissance aristocratic daughter into a heroine of tragic stature. Given that Shakespeare and Conrad are writing from polar humanist traditions, one could argue that Victory constitutes a parody of The Tempest. Hence, Prospero's enlightened dream of man's unlimited power regulating the disruptive forces of nature and producing the humanist utopia of a "brave new world" (Tempest, V.1), is mocked by the pitiable demise of the T. B. C. C. and a "stride forward" in "the general organization of the universe" (Victory 21), which "that once sanguine enterprise" (Victory 149) was supposed to represent.

While comparing the plots of Victory and Romeo and Juliet, we find out that they are virtually identical in essentials, suggesting that Shakespeare's play must have been on Conrad's mind when he was composing his novel. Both works begin with a disillusioned idealist trying to flee from his inner conflict by pursuing solitude and avoiding involvement in life. A perfect solution to the character's emotional problems appears in the form of a female love object, who breaks down his reticence and engenders the fantasy of a romantic escape. The initial joy of the lovers' tryst and courtship gives way to a sense of despair as they face obstacles to their union, which make it difficult for them to enjoy their newly-found love. This difficulty is temporarily overcome by the elopement plan which allows the lovers to remove themselves "out of the world" (Victory 77) and create an erotic haven, which is, however, marred by the deceptiveness of nocturnal fantasies and therefore presented as vulnerable to the sunlight of the waking reality. It is interesting that Romeo and Juliet's private world of love representing a desire to return to the primordial union of the two sexes is realized in Victory in the form of Samburan where Heyst and Lena retire to live alone in a prelapsarian state of bliss. The complications begin when a man's death in which the tragic hero is directly or indirectly implicated (Tybalt, Morrison) sets into motion a chain of events that leads to the forced separation of the two lovers and threatens their relationship. To add to this, a rival suitor appears (Paris, Ricardo), and, taking advantage of the absence of the hero, tries to claim the heroine for himself. At this point the second plot is set into motion in which the heroine is meant to play dead until the threat of the suitor is surmounted and the hero can return and reclaim her. However, due to a combination of bad luck and a breakdown in communication the plot backfires and the lovers end up confronting death separately, on their own, succumbing to the latent death-wish that was an essential part of their motivation from the start.

Of course, there are differences of emphasis between the two plots. What is not so obvious in Romeo and Juliet but which Conrad's novel brings out is that it is not just the heroine that is courted all throughout by the rival lover, but so is the hero, for this rival is none other than Death, whose attraction appears too powerful for the hero to 
resist once the heroine is out of the picture. Also the tension in Romeo and Juliet results from a seemingly external conflict: between civic law, on the one hand, and sexual desire, on the other hand, turning the play into a kind of social drama. In Victory, on the other hand, the basic tension appears largely to be a result of the inner conflict of the protagonist and, in particular, his conscious intention to avoid attachments of any sort vs. his unconscious social/sexual needs, suggesting psychological drama. Moreover, whereas Shakespeare places emphasis on the conflict between generations, showing how through their exemplary self-sacrifice the young lovers manage to overcome their parents' enmity, Conrad structures his work around gender and shows women as redeeming the men.

The power of fate influencing human affairs is equally stressed in both works. Although in Romeo and Juliet there are many turning points, where the plot could have taken a different direction and made the play a romantic comedy, this never happens for the lovers are "star-crossed," to use the Prologue's famous phrase. Similarly, Victory emphasizes man's helplessness to determine the course of his/her life, as it follows from Davidson's concluding words: "There was nothing to be done [...] Nothing!" (Victory 328), and which are analogous with Friar Lawrence's fatalistic remark at the end of Romeo and Juliet: "A greater power than we can contradict / Hath thwarted our intents" (V.3.153-4). An echo of Friar Lawrence's words: "Heaven and yourself / Had part in this fair maid. Now heaven hath all" (IV.5.66-67) likewise resounds in Davidson's remark at the end of Conrad's novel: "Let heaven look after what has been purified" (Victory 327). In fact, the tragic epilogue in Victory mirrors that of Shakespeare's play quite closely, complete with a high-ranking authority figure being wheeled on stage for the purpose of closure and a customary restoration of order. However, both Prince Escalus in Romeo and Juliet and His Excellency in Victory are deliberately drawn rather flat so that the stable world of social hierarchy and cultural values they are supposed to represent pales before the chaos and carnage that have just preceded, thereby heightening the final tragic effect.

Thus, far from being a Tempest-like comedy, Victory resembles a romantic tragedy like Romeo and Juliet, albeit with greater emphasis on the tragic than the romantic. Yet, a fusion of different, often incompatible, genres that Shakespeare so masterfully includes in his work is also, to some extent, noticeable in Conrad's novel. Romeo and Juliet constitutes a typical example of Renaissance experimentation with form in that it begins as a comedy and gradually becomes darker and more tragic, without however, completely relinquishing its comic side. Hence the most innovative aspects of Shakespeare's romantic tragedy amount to frequent alternations between the comic and the tragic, which results in a number of scenes evoking both pity and merriment. Those include Mercutio's death scene, where Romeo is complaining to the Friar about his banishment, and the scene of the discovery of the seemingly 'dead' Juliet on the morning she is to marry Paris.

Victory also entails overlapping genres resultant from temporal dislocations of the narrative and coincidences involving different types of characters. Thus, chronologically, the story which begins as black farce, with the mismatched Morrison-Heyst partnership giving rise to the absurd dream of excavating tropical coal, becomes a ro- 
mance, with Heyst rescuing Lena, to finally end in the manner of tragic allegory, with "evil intelligence, instinctive savagery" and "brute force" (Victory 267) invading the lovers' Samburan sanctuary. Moreover, as in Romeo and Juliet, the comic, or the ironic, is rarely absent from the narrative, and is often associated with the two stock comic characters of the novel: Schomberg, the mercenary innkeeper, a lecher and a poltroon; and Ricardo, the wily servant and braggart turned courtly lover. We even find in Victory a typical Shakespearean juxtaposition of a wedding and a funeral, as a day after the liquidation of the T. B. B. C., Wang marries his Alfuro wife, with the customary wedding celebrations following the event. The tone of Victory is also inconsistent, with Heyst often in a state of veiled mourning, even when allegedly in love, and Lena's rescue a somewhat desperate affair, verging on hopelessness, with her supposed protector realizing that he is "disarmed."

Finally, both works depict a horizontally structured society, ranging from higher nobility to lower classes. However, although Romeo and Juliet reaffirms the aristocratic ideology of Aristotelian tragedy by basing class differentiaation on ethical differences, Victory appears to be rather comic in subverting this model. Hence, the narrator of the novel ironically claims that "besides being a gentleman," Morrison "was also an honest fellow" (Victory 29), thereby differentiating between the two concepts. At the same time Conrad presents the lowborn Lena rather than the highborn Heyst as "heroically equal to every demand of the risky and uncertain future" (Victory 16).

The next level of affinity between Victory and Romeo and Juliet concerns the similarities between individual characters. Although Shakespeare's tragic hero and heroine are in their early teens and come from families "both alike in dignity" (Prologue), they can in many respects be said to constitute the prototypes of Conrad's protagonists in Victory. Firstly, Heyst's reputation as "the wanderer of the Archipelago" (Victory 68) on an "aimless pilgrimage" (Victory 39) around the islands of North Borneo is astoundingly close to the significance of Romeo's name in Shakespeare's time, i. e., that of 'a pilgrim to Rome,' a 'roamer' and 'wanderer.' Our first impression of Heyst is that of a person suffering from depression, for he is not only disappointed in himself for having got involved with Morrison, but he is also said to be "disenchanted with life as a whole," with those "sharp contradictions that lacerate our intelligence and our feelings" (Victory 68).

Similarly, Romeo, another "gentleman" (I.5.66), dreamer, and utopian, is initially heart-broken over Rosaline, but in fact ridden with a wider dissatisfaction, as the following oxymoronic lines suggest:

$\mathrm{O}$ anything of nothing first create!

O heavy lightness, serious vanity,

Misshapen chaos of well-seeming forms,

Feather of lead, bright smoke, cold fire, sick health,

(I.1.178-82)

Moreover, both disenchanted idealists are initially presented as mysterious, aloof, and antisocial, associating with the natural world rather than the human one. Thus, 
Romeo is said to be "[a]dding to clouds more clouds with his deep sighs" (I.1.133), while the smoking Heyst is compared to the volcano, "making in the night same sort of glow and of the same size" (Victory 20). In the heyday of the T. B. C. C., Heyst is said to have become "very concrete, very visible" (Victory 35), but when the dream of the tropical coal fades away, he returns to his former invisibility, which is reminiscent of Romeo's habit of vanishing and reappearing as he falls in and out of love with Rosaline. Although, following the liquidation of his company, Heyst is determined to remain "inert" (Victory 19) and abstain from any social intercourse whatsoever, "the sight of his kind was not invincibly odious to him" (Victory 40), and, as observed by the narrator, he suddenly reappears in Schomberg's hotel where he forms his second and ultimately fatal attachment with another suffering human being. Similarly, Romeo, who vows that he will never again love anyone after Rosaline, is lured by his friends to the Capulet feast where he meets a woman that puts an end not only to his obsession with Rosaline but also, ultimately, to his life. Benvolio's advice to Romeo: "Take thou some new infection thy eye" / "And the rank poison of the old will die" (I.2.49-50), implying that relationships are akin to fatal diseases, is mirrored in Heyst's words: "he who forms a tie is lost. The germ of corruption has entered his soul" (Victory 169).

Concerning the female protagonists, although the phrase "that poor little girl" (Victory 208), which is used in relation to Lena in Conrad's novel, seems more suitable for the fourteen year-old Juliet laid in the Capulet tomb than the experienced and plucky orchestra girl, it does betray Conrad's intention of modelling his tragic heroine on Shakespeare's. However, both young women display a child-like quality, as when the newly wedded Juliet describes herself as "an impatient child that hath new robes / And may not wear them" (III.1.30-31), and the wounded Lena is said to take Ricardo's knife into her hands "with the innocent gesture of a child reaching eagerly for a toy" (Victory 323). Moreover, both Lena and Juliet are only daughters in their families, whose histories are marked with death, Lena having lost both her parents and Juliet a number of siblings. Thus, the latter is presented as a girl wedded to death while the former is called "a girl wedded to misery" (Victory 204). The similarities extend even to the two young women's parents, as Lena's father is said to have been a musician in theatre orchestras, a detail which seems to ally him with the fun-loving Capulet, hosting the feast in Act I of Shakespeare's play. The two tragic heroines also seem to share common character traits, particularly that of fidelity, which prompts their loyalty to their chosen partners, even unto death. Thus, just as Juliet promises Romeo that she will "prove more true / Than those that have more cunning to be strange" (II.2.100-101), Lena asserts that she "may not be of much account" but she knows "how to stand by a man" (Victory 84). They also display a pragmatism not normally associated with adolescence, which is markedly absent from their older male partners and enables them to "defend [their] own" (Victory 244), even at the cost of compromising their moral standards. Hence, neither heroine has qualms about employing subterfuge to overcome the impasse they find themselves in, Juliet pretending to her father that she is content to marry Paris and has repented "of the sin / Of disobedient opposition" (IV.2.17-18) to his will, and Lena hiding her true feelings 
from Ricardo for as long as it takes to disarm him. Finally, both heroines display remarkable courage, with Juliet declaring to Friar Lawrence "the strength of will to slay [herself] (IV.1.74), and Lena defending herself against Ricardo "with a determination which could hardly have been expected from a girl" (Victory 239). Clearly the behaviours of both tragic heroines lay bare the shortcomings of the patriarchal stereotypes relating to gender, or, as Davidson remarks to Heyst about Mrs. Schomberg's part in the elopement, "There's a lot of unexpectedness about women" (Victory 57).

Another character comparison between the two works, i. e., one between Davidson and Friar Lawrence, can prove quite revealing. Like the Franciscan friar in Romeo and Juliet, Davidson is described as a "stout" (Victory 49) yet "sensitive" man (Victory 48), with a "capacity for sympathy" (Victory 49) and "invincible placidity" (Victory 50). He also represents something of the reality principle in the novel, calling Heyst's elopement a "[w]onderfully quick work," which is, however, likely to lead to "[r]epentance" (Victory 50). This brings to mind Friar Lawrence's remark addressed to Romeo, to "love moderately. Long love doth so. / Too swift arrives as tardy as too late" (II.6.14-15). Despite his misgivings, Heyst's "self-appointed protector" (Victory 44) and confidant similarly assists him in the ill-advised elopement by returning Mrs. Schomberg's shawl and regularly passing by Samburan to discreetly check on the lovers' safety. Like Friar Lawrence, who arrives too late to save Romeo in the tomb, Davidson lands on Samburan on the night of the storm but is unable to stop the tragic course of events. What's more, both characters are the speakers in the tragic epilogues of both works.

Regarding the minor characters, Tybalt's role is initially analogous to that of Schomberg, who, like Juliet's cousin, ultimately takes revenge on his rival for the insult to himself caused by the lovers' tryst, finally making Heyst "pay for [his] fun" (Victory 305). In his vanity and foolishness, Schomberg also resembles Romeo's other rival, Paris, in that both men assume that their masculine charms render them irresistible to the tragic heroines. Thus, Schomberg is said to have pardoned Lena's signs of aversion to him "on the score of feminine conventional silliness" (Victory 88), while Paris, similarly, misinterprets Juliet's snub in Lawrence's cell as an expression of feminine modesty, coupled with the effects of her mourning her cousin. In his role of the "Prince of cats" (I.4.19), who can "scratch a man to death" (III.1.100-101) with one stroke of his sabre, Tybalt closely resembles Ricardo, "the stealthy, deliberate wildcat turned into a man" (Victory 105), who is equally famed for his skill in the use of a knife and is also presented as a rival to the love of a woman. Interestingly enough, neither of these much vaunted duellists lives up to his reputation, although not before they have seriously compromised their rivals. Death, which plays such a prominent part in Romeo and Juliet, especially on the morning when Juliet is discovered, following her intake of the deadly potion (cf. Capulet's exclamation: "Death is my son-in-law. Death is my heir. / My daughter he hath wedded" [IV.5.38-39]), in Victory appears under the guise of Mr. Jones, the "masquerading skeleton out of a grave" (Victory 312), who similarly, although indirectly, deprives the tragic hero of his beloved by taking his life. And finally, if Mrs. Schomberg can be considered the lovers' female go-between, or matchmaker, akin to the Nurse in Romeo and Juliet, 
it is difficult to imagine two more contradictory creations, for the former resembles a mechanical and lifeless automaton who barely opens her mouth, while the latter is one of the most lively, spontaneous, and voluble characters ever to appear on stage. On the other hand, things may not be as they appear to be because, eventually, Mrs. Schomberg's outwardly comatose bearing turns out to be no more than a comic mask concealing a life-affirming desire to "defend her position in life" (Victory 58), thus making her, in the words of Davidson, "the greatest wonder of all, astonishing and amusing" (Victory 61).

Another level of affinity between the two works relates to scenes that mirror each other. The most obvious example of such mirroring connects the Capulet feast in Romeo and Juliet and the Zangiacomo concert in Victory, where the lovers first meet. It is interesting that Conrad should have given the latter scene a flavour of a Renaissance feast by calling Lena's smile "the best of masks" (Victory 85) and referring to the "music of the spheres" (Victory 68) that dreamers like Heyst are wont to hear. Moreover, Lena's orchestra is given a Latin theme, reminiscent of the Italian setting of Romeo and Juliet, yet the fact that Signor Zangiacomo is "really a German who only dyes his hair and beard black for business" (Victory 46), while none of the performers in his orchestra is actually Italian, serves to de-romanticize the situation in preparation for a more self-conscious modernist version of the archetypal love scene, which follows. When Romeo first sets eyes on Juliet, he exclaims: "Did my heart love till now? Forswear it, sight / For I ne'er saw true beauty till this night" (I.5.52-3); Heyst is likewise struck by a unique, albeit more cerebral, experience of marking in Lena's features "more fineness than those of any other feminine countenance he had ever had the opportunity to observe" (Victory 74). The imagery used by both writers to describe the women in these scenes is surprisingly similar: from Davidson's observation that "some of these orchestra girls are no chicks" (Victory 47), reminiscent of Romeo's image of Juliet as a "snowy dove trooping among crows," to the light imagery associated with Lena's "white muslin dress," "slender white bust," and "white shoes" (Victory 71), etc., which evokes Juliet's teaching "the torches to burn bright!" (I.5.44). Even Romeo's famous comparison of Juliet to a "rich jewel in an Ethiop's ear" (I.5.46) may be seen as echoed in Lena's admission that the "quantities of 'black men' all about frightened her" (Victory 77), thus suggesting a distinctiveness as well as vulnerability typical of tragic protagonists. Indeed, Lena feels that Heyst is "as different from the other men in the room as she was different from the other members of the ladies' orchestra" (Victory 73).

In keeping with the tradition of courtly love, which informs the lovers' relationships in both works, the love object in each is idealized and the erotic impulse spiritualised, to be finally aligned with religious devotion. Thus, the Swedish Baron is inspired to address the so-called "princess of Samburan" (Victory 165) with such phrases as, "pray command me" (73), or "Is it your wish that I should leave you?" (73), while encouraging Lena to cling to her prince "after the manner of supplicants all the world over" (80), as well as making her feel that she could never "appease some exalted and delicate desire of his superior soul" (268). Moreover, in their encounter scene Romeo sees a "Beauty too rich for use, for earth too dear" (I.5.47) in 
Juliet, while Heyst observes that "everything in the hall were dirt" (Victory 72) under Lena's feet. Consequently, both men adopt a posture of worshippers of their deified female figures, who must, at least initially, remain cold and aloof to curb masculine fantasies.

In response to Romeo's role of a pilgrim approaching to bestow a kiss on his saint's statue, Juliet at first keeps him at bay by saying that pilgrims can also obtain favour by simply touching their idol; in response to Heyst's chivalric "Excuse me but that horrible female has [...] pinched you, hasn't she?" (Victory 73), Lena replies: "Suppose she did - what are you going to do about it?" (Victory 73). In Shakespeare's day Petrarchan diction and the courtly love tradition were well established in England and very fashionable, which justifies Romeo and Juliet's florid conceits and stylised courtship. But the same can hardly be said for Victory's unromantic era in which there is "nothing worth knowing but facts" (Victory 22), so Heyst's behaviour in this scene is as misplaced as Heyst himself is in Schomberg's hotel. Indeed, although the occasions for both encounters are ostensibly festive, the fact that the male lovers represent intruders, having, as it were, gate-crashed the party, creates an atmosphere of imminent danger, thus intensifying the erotic and the transgressive undertones of the scene, in the manner in which a lady's inaccessibility excites the sensibilities of her courtly lover. Thus, Schomberg, who is observing Heyst throughout the scene, is incensed by the presence of his arch enemy, and proclaims: "I really don't know why he has come to stay in my house [...] for twopence I would ask him to go and seek quarters somewhere else" (Victory 68), a sentiment which is remarkably close to Tybalt's "What dares the slave / Come hither, covered with an antic face, [...] Now by the stock and honour of my kin, / To strike him dead I hold it not a sin" (I.5.55-9).

Given all the similarities between Victory and Romeo and Juliet on the level of genre, plot, and characterization, it would be surprising if they were not reflected in the themes and motifs of the two texts, where in fact they are the most numerous and conspicuous. One of those, also briefly mentioned by Gillon, is the theme of names and books, which appears to be more significant than implied by Gillon, as it relates to the issues of language, the symbolic order of culture, and the relationship between the signifier and the signified, hence those at the heart of textual problematics. Although Gillon connects Victory to Hamlet and Coriolanus in this context, to no other Shakespeare's work are these problems more central than to Romeo and Juliet, with its most famous of line: "O Romeo, Romeo! - wherefore art thou Romeo?" (II.2.33), as well as the related "that which we call a Rose / By any other name would smell as sweet" (II.2.43-4). One may well wonder why Gillon, or other critics, have not noticed this rather obvious connection. The answer, I believe, lies in the fact that Romeo and Juliet has crossed the arbitrary, yet academically significant, borderline separating highbrow literature from popular romance-a line which, incidentally, Conrad's work has made a habit of crossing - and which has resulted in it being frequently dubbed as unworthy of serious scholarly consideration.

Nevertheless, following up on the name and book theme in Shakespeare's romantic tragedy, one could claim that just as Lady Capulet views Juliet's feminine form as a perfect sort of dressing, or complement, to Paris's masculine content, so is Romeo's 
name viewed by Juliet as an artificial and a relatively inconsequential appendage to Romeo, the actual man. Yet, the name is ultimately the one thing that becomes immortalised, for Romeo falls in love, marries, kills, and dies but his name survives all those events, which are apparently more significant than his baptism. Similarly, although Heyst resolves to live in a state of nature, outside the oppressive conventions and corrupting influences of the society, on a desert island, which, since Robinson Crusoe has denoted sovereign and self-determined individualism, he still ventures as far as Sourabaya to see "if there were any letters for him at the Tesmans" (Victory 40) and eventually does become involved in communal life. For, if Heyst, the would-be hermit, needs "letters," he needs words, language, and the whole social structure that goes with the former. So, when Juliet asks: "What's in a name?" (II.2.43), indirectly questioning the society's power to determine the life of an individual, the answer turns out to be: 'quite a lot,' for, by the end of the balcony scene, she imagines making the voice of the mythical Echo hoarse "[w]ith repetition of [her] Romeo's name" (II.2.161-3).

In fact, through their sexual unions and the adoption of new identities symbolized by new names, both pairs of lovers are metaphorically reborn. Thus, Lena says to Heyst: "you give me a name [...] something quite new"(84); while Romeo asks Juliet: "Call me but love, and I'll be new baptized. / Henceforth I never will be Romeo" (II.2.50-51). However, the name which Heyst comes up with for Lena is "Magdalen," which is essentially no different from the name she used to go by (Magdalen $\rightarrow$ Magdalena $\rightarrow$ Lena); and although Romeo and Juliet quite frequently call each other "love," their newly adopted identity does not have the power to expunge either their actual Christian names, or the irreconcilable social differences between their families, which are conveyed by their surnames. Thus the controlling power of the name and the society to which it belongs is emphasized by the book image, which recurs in both texts, as if to remind the lovers of the inflexible nature of law, which is represented here by the immortalising, culturally transmitted inscriptions passed down from one generation to another, through writing. Thus, Romeo says to Juliet as they are about to part: "Love goes towards love as schoolboys from their books" (II.2.156); while the love affair in Victory passes in the shadow, both literally and metaphorically, of the late Heyst Senior's library, which invades their refuge in Samburan as destructively, one could say, as the desperadoes from Sourabaya.

Language is viewed in both texts as a means of social control and the prime expression of the subject's will-to-power, for an object is named in order to be dominated and a word indelibly brands the thing it innocently seems to attach itself to. Thus Heyst has the misfortune not only of being labelled in diverse ways by people that are generally hostile to him, but also by anything anyone says about him, which "stuck to him and became part of his name" (Victory 22). In a similar way, Romeo confesses to Juliet: "My name [...] is hateful to myself / Because it is an enemy to thee" (II.2.55-6); while Heyst, who is slanderously labelled by Schomberg "the Enemy," seems to suffer from the same problem, of getting rid of the names that other people randomly attach to him. While Romeo asks: "[...], tell me / In what vile 
part of this anatomy / Doth my name lodge? [...] that I may sack / The hateful mansion" (III.3.106-9), implying that one cannot excise one's name and survive the operation, Heyst, ironically, seems to be destroyed by nothing else than the epithet of the "destroyer" (Victory 35), which is given to him by Schomberg. The etymology of Heyst's name, which derives from the German verb heissen ("to name") sums up the problem very well, for if a thing is defined by its name, the Swedish Baron is no more than the sum total of the names given to him by others. The image of Heyst as Adam trying to name the other creatures of "that Paradise which he was so soon to lose" (Victory 149) suggests that Lena is just another creature in that Paradise awaiting to be verbally possessed by the proprietor of language, or the "talking animal" (55), to borrow the phrase from Under Western Eyes. However, Conrad makes this linguistic appropriation fail since Lena disobeys Heyst's instructions on the night of the storm and carries out her own plan to defeat the desperadoes. Nevertheless, the fact that, besides being presented as subject to patriarchal control, she is also cast in the role of Heyst's and other men's lost Paradise, even the ideal of a pre-linguistic utopia is linguistically constructed, like Lena's own identity, so there is no escaping words, either in the social or the psychological domain.

The issue of naming and the related problem of language comes to mind in two analogous recognition scenes in Victory and Romeo and Juliet. In Shakespeare's tragedy this is a scene in which the Nurse is trying to inform Juliet of Tybalt's murder but is initially misunderstood by her charge, who thinks that it is Romeo who is dead. The result is that the news of Tybalt's death only gradually dawns on Juliet, just as in Victory it takes a long time for Lena to realize that the name which she hears referred to in Sourabaya in connection with a vile crime is the name of Heyst's late friend and business partner, Morrison. In both cases, the power of language seems to be at least as great as what it describes, for the mere mention of the late men's names, like the word "banished," uttered by the Prince as punishment for Romeo's crime, has the power to kill the listener. Thus, when the truth sinks in, Lena whispers Morrison's name twice and her head is said to droop as if foreshadowing her death later in the novel (Victory 173), while Juliet exclaims “'Romeo is banished' - / There's no end, no limit, measure, bound, / In that word's death" (III.2.124-6). Even if these texts may not necessarily concur with St. Paul's words that "the spirit giveth life," they leave no doubt as to the fact that "the letter killeth" (II Corinthians 3:6).

It should be clear by now that Romeo and Juliet has been largely neglected in criticism that has sought parallels between Conrad and Shakespeare, especially as regards Victory. Indeed, a close comparative reading of those two romantic tragedies reveals very specific affinities on the level of genre, plot and characterization, with whole scenes in Conrad's novel mirroring those in Shakespeare's play. In addition, the affinities between the two texts can be seen as likewise extending to their themes and motifs, such as the issue of naming, which in turn relates to the crucial problematics of language and signification. The explanation for this must be sought for in either a conscious attempt on Conrad's part to imitate Shakespeare's art, or involuntary emulation, whereby the novelist had so far assimilated the Bard's work that he followed him automatically and unconsciously while composing his own fiction. 
If the former is the case, it by no means lessens Conrad's achievement in such works as Victory, which reveals a remarkable power to collate existing literary styles and modes into a vivid and compelling narrative, comparable to the synthesizing tendencies of Renaissance poetry. If it is the latter that is true, we are confronted with a most extraordinary example of cryptomnysia, or "hidden memory," which has as yet to be explored in greater depth but which may hold the key to the phenomenon of Joseph Conrad and his achievement as a Modernist.

\section{WORKS CITED}

Baines, Jocelyn. Joseph Conrad: A Critical Biography. London: Weidenfeld and Nicolson, 1960. Bradley, A.C. Shakespearean Tragedy: Lectures on Hamlet, Othello, King Lear \& Macbeth, London: Macmillan, 1904.

Conrad, Joseph. Victory. Harmondsworth: Penguin Books, 1994.

"Heart of Darkness." Penguin Twentieth Century Classics. Ed. Paul O' Prey.

Harmondsworth: Penguin Books,1989.

Under Western Eyes. Penguin Twentieth Century Classics. Ed. Boris Ford. Harmondsworth: Penguin Books, 1985.

Dike, Donald A. "The Tempest of Axel Heyst." Nineteenth Century Fiction 17.9 (Sept. 1962): 95-113. Freud, Sigmund. The Standard Edition of the Complete Psychological Works of Sigmund Freud. 24 Vols. Eds. J. Stratchey \& Anna Freud. London: The Hogarth Press, 1961.

Gillon, Adam. Conrad and Shakespeare and Other Essays. New York: Astra Books, 1976.

Holy Bible, The New International Version (1973). $3^{\text {rd }}$ Reprint. Colorado Springs: International Bible Society, 1984.

Jean-Aubry, G. Joseph Conrad: Life and Letters. 2 Vols. Garden City, NY: Doubleday, Page \& Co., 1927.

Karl, Frederick R. A Reader's Guide to Joseph Conrad. New York: The Noonday Press, 1960.

Lodge, David. "Conrad's Victory and The Tempest: An Amplification." Modern Language Review LIX (April 1964): 195-99.

Shakespeare, William. Hamlet. The Arden Shakespeare. Ed. Harold Jenkins. London: Methuen, 1985. . Romeo and Juliet. Penguin Shakespeare. Ed. T.J.B. Spencer. London: Penguin, 2005. . The Tempest. Penguin Popular Classics. Harmondsworth: Penguin, 1995. 